\title{
Coetaneous catalytic kinetic resolution of alkynes and azides through asymmetric triazole formation
}

\author{
William D. G. Brittain ${ }^{1,6}$, Andrew G. Dalling ${ }^{1,6}$, Zhenquan Sun ${ }^{1,2}$, Cécile S. Le Duff ${ }^{3}$, \\ Louise Male ${ }^{4}$, Benjamin R. Buckley ${ }^{5 *}$ \& John S. Fossey ${ }^{1 *}$
}

A non-enzymatic simultaneous (coined coetaneous) kinetic resolution of a racemic alkyne and racemic azide, utilising an asymmetric CuAAC reaction is reported. The use of a $\mathrm{CuCl}(R, R)$-Ph-Pybox catalyst system effects a simultaneous kinetic resolution of two racemic starting materials to give one major triazolic diastereoisomer in the ratio 74:12:4:10 ( $\mathrm{dr} 84: 16,90 \%$ ee maj). The corresponding control reaction using an achiral copper catalyst gives the four possible diastereoisomers in a 23:27:23:27 ratio, demonstrating minimal inherent substrate control.

The copper-catalysed azide-alkyne cycloaddition (CuAAC) pioneered by both Meldal and Sharpless has become a ubiquitous molecular fragment-linking reaction ${ }^{1-3}$. The product 1,4-substituted, 1,2,3-triazoles, along with their alkyne and azide building blocks, in enantioenriched forms are important motifs ${ }^{4-9}$. Triazoles for example, have become crucial to research arenas including fragment based drug discovery (FBDD) and supramolecular chemistry $^{10}$. Whilst scalemic alkynes and azides are important building blocks for a myriad of transformations ${ }^{4,5}$.

Catalytic kinetic resolution (KR) occurs when one enantiomer of a racemic substrate is preferentially activated towards reaction by a chiral catalyst (through competing diastereomeric transition states), leading to more rapid formation of one enantiomer of product. At $50 \%$ conversion of starting racemic material, effective catalytic KR will have occurred if high $e e$ of product and high ee of unreacted starting material are obtained. The effectiveness of a kinetic resolution may be judged by a criterion named selectivity factor $(s)$. Selectivity factor is the ratio of the rate constants for reaction of each enantiomer in a given asymmetric transformation ${ }^{11}$. Enzymes are capable of performing catalytic KR, albeit under a narrow range of conditions with limited substrate scope ${ }^{12,13}$. Kinetic resolution has been widely studied ${ }^{11}$. Fu and co-workers have championed catalytic KR, applying planar chiral DMAP-derivative catalysts to the successful KR of secondary alcohols ${ }^{14-16}$. Catalytic KR has also been successfully employed in copper-catalysed azide-alkyne cycloadditions leading to enantioenriched chiral triazoles and the recovery of enantioenriched starting materials (Scheme $1 \mathrm{i}$ and ii) ${ }^{17-21}$, and complete consumption of starting materials in the case of dynamic kinetic resolution ${ }^{22}$. Desymmetrisation by asymmetric triazole formation has also been successfully achieved ${ }^{23-25}$.

Parallel kinetic resolution is a well-established field, where a single chiral starting materials' enantiomers undergo simultaneous divergent asymmetric transformations yielding different enantioenriched products from either enantiomer of starting material ${ }^{26-29}$. For example $\mathrm{Fu}$ and co-workers utilised parallel kinetic resolution to resolve 4-alkynals (Scheme 2$)^{30}$.

Herein, we investigate a simultaneous, rather than parallel, kinetic resolution of two racemic substrates, under control of a single chiral catalyst, and coin the term coetaneous resolution to describe it. Upon coetaneous resolution of two racemic substrates, the ideal scenario would be formation, at $50 \%$ conversion, of a single diastereoisomer of the product formed from one enantiomer of each substrate. This ideal process would leave the opposite

\footnotetext{
${ }^{1}$ School of Chemistry, University of Birmingham, Edgbaston, Birmingham, West Midlands, B15 2TT, UK. ${ }^{2}$ School of Chemistry and Chemical Engineering, Sun Yat-Sen University, 135 Xingang Rd. W., Guangzhou, 510275, China. ${ }^{3}$ NMR Facility, School of Chemistry, University of Birmingham, Edgbaston, Birmingham, B15 2TT, West Midlands, UK. ${ }^{4}$ X-Ray Crystallography Facility, School of Chemistry, University of Birmingham, Edgbaston, Birmingham, West Midlands, B15 2TT, UK. ${ }^{5}$ Department of Chemistry, Loughborough University, Loughborough, Leicestershire, LE11 3TU, UK. ${ }^{6}$ These authors contributed equally: William D. G. Brittain and Andrew G. Dalling. *email: b.r.buckley@ Iboro.ac.uk; j.s.fossey@bham.ac.uk
} 

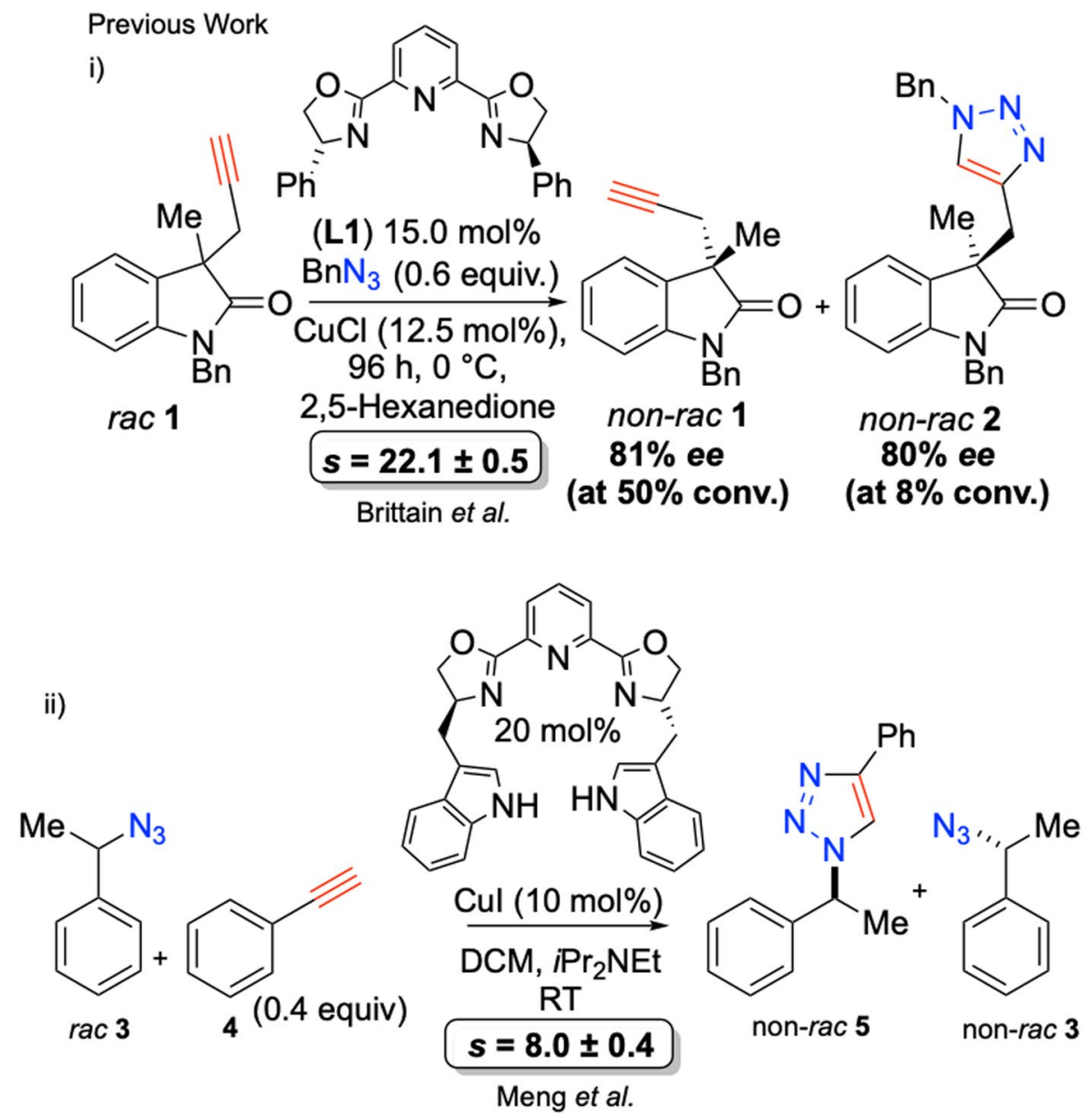

Scheme 1. Previous Work: (i) Kinetic Resolution of Alkynes by Brittain et al. ${ }^{18}$. (ii) Kinetic Resolution of Azides by Meng et al. ${ }^{20}$.

enantiomers of the substrates unreacted in high enantiopurity. Thus, simultaneously kinetically resolving two chiral starting materials under one reaction and product manifold.

We chose to focus on the CuAAC of racemic substrates, such that, under catalyst control, the starting materials (chiral azides and alkynes) could react selectively to give a major stereoisomer, among the four possible expected diastereomeric triazole products. Conversely, in the case where no substrate control exists, the use of an achiral catalyst will lead to equal consumption of starting material enantiomers and delivery of an equimolar distribution of the four stereoisomers of product (Fig. 1). Asymmetric synthesis using two catalysts to control the formation of two stereogenic centres has been elegantly demonstrated by Carreira and co-workers. See refs ${ }^{26,27,31,32}$.

\section{Results and Discussion}

Based on previous work on catalytic kinetic resolution of alkynes and azides, we chose the PyBox ligand family for creation of a chiral copper catalyst and selected $(R, R)$-Ph-PyBox as a suitable ligand for our investigations $\mathrm{s}^{20,25,33,34}$. To investigate the potential for coetaneous catalytic kinetic resolution we focused on substrates with demonstrable efficacy in standard catalytic kinetic resolutions. Quaternary oxindole $\mathbf{1}$ (as employed in Scheme 1i), was selected as the alkyne-containing component. Oxindoles are important, biologically-relevant, scaffolds having found wide application, including as calcium channel blockers ${ }^{35}$, anti-angiogenics ${ }^{36}$, antitumour agents $s^{37-39}$ and analgesics ${ }^{35}$. Azide 3 (as employed in Scheme 1ii) was chosen owing to its previously reported application in the first catalytic kinetic, copper-catalysed triazole forming, resolution by Fokin and co-workers ${ }^{20}$.

We have previously explored the selectivity of alkyne $\mathbf{1}$ towards kinetic resolution and found an intriguing solvent dependency upon selectivity ${ }^{18}$, however resolution of azide 3 had not been employed under those same conditions (shown in Scheme 1i). In order to probe this azide 3 was reacted with 0.5 equivalents of phenyl acetylene, $15 \mathrm{~mol} \% \mathrm{Ll}$ and $\mathrm{CuCl}(12.5 \mathrm{~mol} \%)$ in acetone- $d_{6}$ and the reaction progress was monitored in-situ via proton nuclear magnetic resonance ( ${ }^{1} \mathrm{H}$ NMR) spectroscopy.

From the resolution of azide 3 in acetone a selectivity factor of $s=7.4$ was determined (Table 1, entry 1). Since, resolution of alkyne 1 had been shown to be superior, in a previous study, when 2,5-hexanedione had been employed as reaction solvent the resolution of $\mathbf{3}$ was repeated using this dione solvent (unlocked ${ }^{1} \mathrm{H}$ NMR spectroscopy reaction monitoring, see ESI) which gave conversions and selectivity in line with that when acetone 


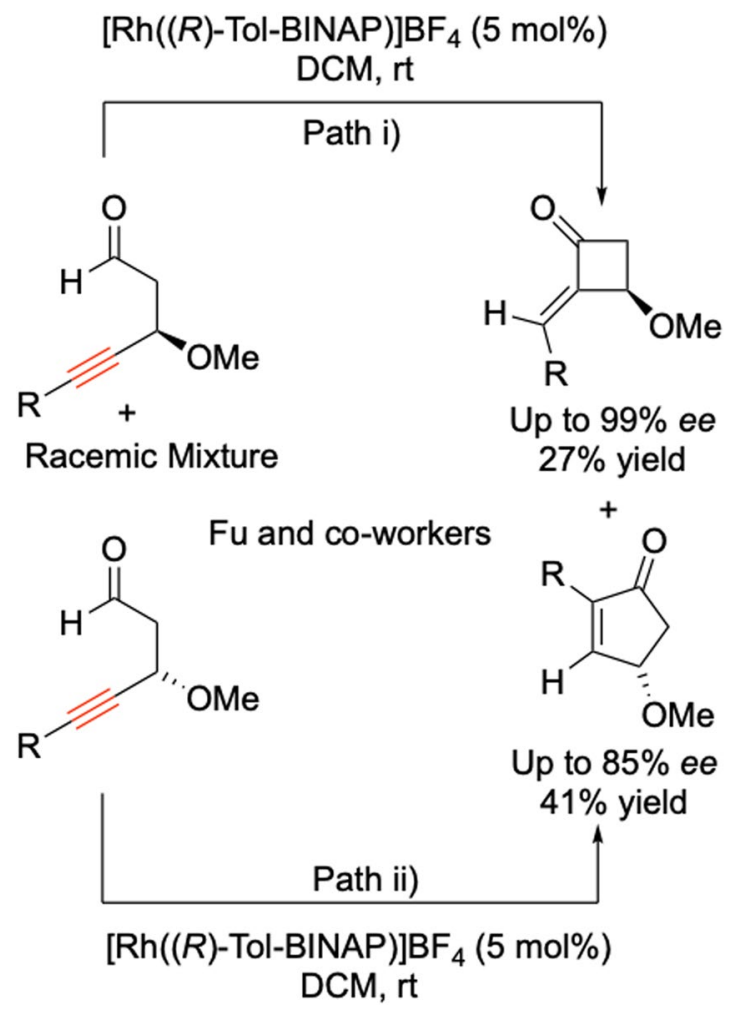

Scheme 2. Parallel Kinetic Resolution of 4-Alkynals, Fu and co-workers ${ }^{30}$ Path (i) Reaction of enantiomer $(R)$ to form cyclobutaneone product. Path (ii) Reaction of enantiomer $(S)$ to form cyclopentenone product.

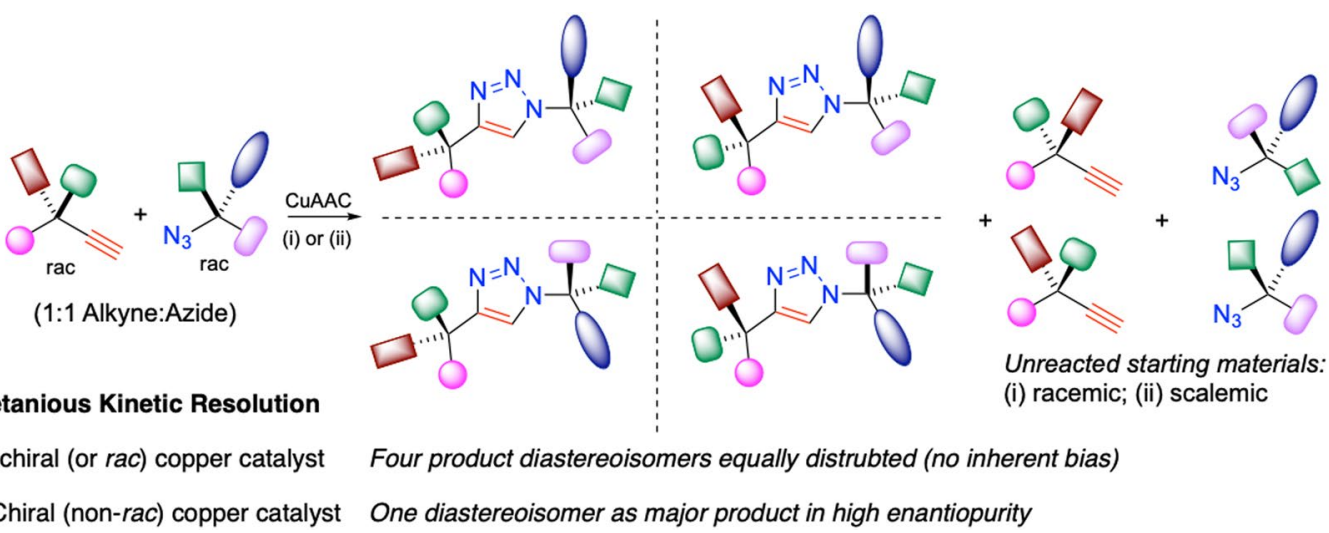

Figure 1. Principle of Coetaneous Kinetic Resolution: (i) the scenario where an achiral catalyst delivers inherent equimolar distribution of diastereoisomers; (ii) the scenario where a chiral catalyst selectively reacts with starting materials.

was used as solvent ( $s=7.1$ ), (Table 1 , entries 1 and 2 versus 3 and 4 ) suggesting that the dione solvent-effect is manifest primarily in alkyne rather than azide selectivity.

The inherent diastereoselectivity of the CuAAC of a reaction of $\mathbf{1}$ with $\mathbf{3}$ was probed (Scheme 3i), to determine any contribution to diastereoselectivity from substrate bias. Compounds $\mathbf{1}$ and $\mathbf{3}$ were reacted together with tris[(1-benzyl-1H-1,2,3-triazol-4-yl)methyl] amine (TBTA) as an achiral ligand giving a product diastereoisomer ratio of 23:27:23:27 via HPLC, thus demonstrating there was little inherent diastereoselectivity between the two substrates in the CuAAC reaction (Scheme 3ii).

The coetaneous kinetic resolution of $\mathbf{1}$ and $\mathbf{3}$ was then attempted. To our delight, it was found that a mixture of $1: 1$ of 3 and $\mathbf{1}$ in the presence of $15 \mathrm{~mol} \% \mathbf{~ L 1}$ and $12.5 \mathrm{~mol} \% \mathrm{CuCl}$ catalyst provided a 74:12:4:10 diastereoisomeric ratio of product $\mathbf{6}$ (Scheme 3iii). This showed that indeed the reaction successfully resolved the two starting materials simultaneously.

To enable comparison of the selectivity for each enantiomer in this diastereo- and enantio- selective process the selectivity factors for each enantiomer of alkyne $\mathbf{1}$ and azide $\mathbf{3}$ were determined as follows. Using enantiopure 


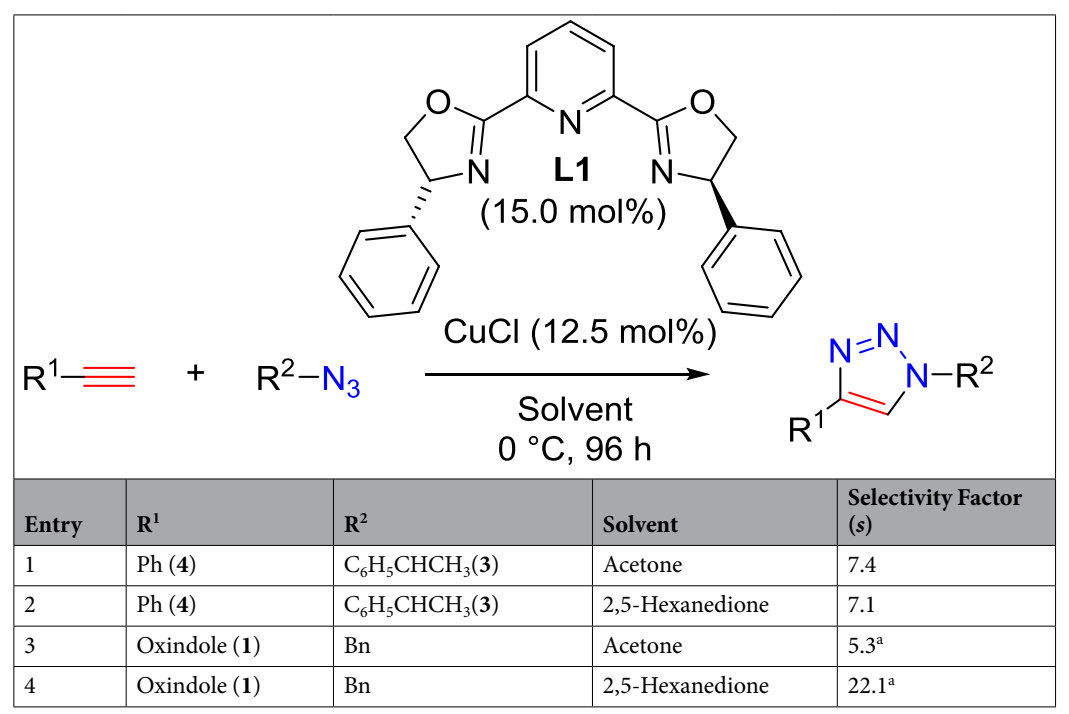

Table 1. Kinetic resolution of alkyne 1 and azide 3 under the same reaction conditions. Reaction was carried

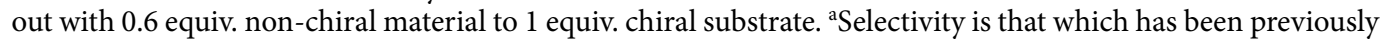
reported by Brittain et al. ${ }^{17}$.

substrates as the limiting reagent the selectivity towards that component could be analysed (Table 2). The absolute configuration of 1 was evidenced by X-ray diffractometry of a single crystal of an iodo alkyne derived from one enantiomer of enantiopure alkyne $\mathbf{1}$ (see compound 7 ESI) and the absolute configuration of $\mathbf{3}$ by comparison to it and by employing in the synthesis literature data and protocols (see ESI). Thus, also allowing for assignment of the absolute stereochemistry of the products (6, as noted in Scheme 3, and see ESI).

From the data presented in Table 2 it can be seen that consumption of racemic alkyne is faster and more selective (in a reaction catalysed by a catalyst derived from L1) in combination with $(S)$ azide. As well as the observation that consumption of racemic azide is essentially equally rapid in combination with either enantiomer of alkyne (in a reaction catalysed by a catalyst derived from $\mathbf{L} 1$ ), with only a slight difference in selectivity, it being subtly better with $(R)$ alkyne. These, and earlier, data reveal two important features, firstly issues of selectivity are more dependent upon alkyne than azide stereochemistry (in this example) and secondly that across these four experiments with a single enantiomer component the faster reacting and more selective examples involve $(S)$ azide and $(R)$ alkyne, which corresponds to the major product (of Scheme 3 iii) being formed from these same two enantiomers. Thus, adding support for the hypothesis that a coetaneous kinetic resolution is taking place.

\section{Conclusions}

These preliminary findings are to the best of our knowledge the first non-enzymatic example of two racemic starting materials being successfully kinetically resolved by the same catalyst to an enantioenriched diastereomeric product. We recognise that in this first study substrate scope is limited and hope this strategy can be applied to other types of substrates and increase the efficiency of resolution procedures. It is interesting to consider if this kind of selectivity may be operating in any systems of nature and we hope to be able to explore the scope and mechanistic aspects of this reaction.

\section{Methods}

Synthesis of (1-Azidoethyl)benzene (3). To a solution of sodium azide (105 mg, $1.61 \mathrm{mmol}, 1.10$ equiv.) in DMSO $(6 \mathrm{~mL})$ was added (1-bromoethyl)benzene $(200 \mu \mathrm{L}, 271 \mathrm{mg}, 1.47 \mathrm{mmol}, 1$ equiv.). The reaction mixture was allowed to stir at $\mathrm{rt}$ for $2 \mathrm{~h}$. To this mixture was added water $(10 \mathrm{~mL})$ and subsequently extracted with ether $(3 \times 10 \mathrm{~mL})$. The organic extracts were combined, washed with water $(2 \times 10 \mathrm{~mL})$ and brine $(10 \mathrm{~mL})$ and then dried over $\mathrm{MgSO}_{4}$, filtered and concentrated under reduced pressure to give (1-azidoethyl)benzene 3 as a pale yellow oil, in $40 \%(84.0 \mathrm{mg})$ yield. Characterisation was in agreement with reported literature values ${ }^{40} .{ }^{1} \mathrm{H}$ NMR $\left(300 \mathrm{MHz}, \mathrm{CDCl}_{3}\right) \delta 7.25-7.40(\mathrm{~m}, 5 \mathrm{H}, \mathrm{Ar}-\mathrm{H}), 4.60(\mathrm{q}, J 6.8,1 \mathrm{H}, \mathrm{CH}), 1.52\left(\mathrm{~d}, J=6.8,3 \mathrm{H}, \mathrm{CH}_{3}\right) ;{ }^{13} \mathrm{C}$ NMR $\left(101 \mathrm{MHz}, \mathrm{CDCl}_{3}\right) \delta 140.90,128.80,128.15,126.41,61.12,21.59$; IR $\nu_{\max }(\mathrm{ATR}) / \mathrm{cm}^{-1} 3032,2979,2090,1244$; $\mathrm{MS} \mathrm{AP}^{+} \mathrm{m} / z 120.1\left[\mathrm{M}-\mathrm{N}_{2}+\mathrm{H}\right]^{+}, 105.0\left[\mathrm{M}-\mathrm{N}_{3}\right]^{+}$; GC (CP-Chirasil-Dex CB), FID, $\mathrm{t}_{(S)}=28.1 \mathrm{~min}, \mathrm{t}_{(R)}=28.4 \mathrm{~min}$.

General procedure for the synthesis of enantiopure azides. Under an atmosphere of nitrogen, the corresponding alcohol (2.54 mmol, 1.00 equiv.) was dissolved in anhydrous toluene $(4 \mathrm{~mL})$ to this was added diphenylphosphoryl azide (DPPA) $\left(633 \mu \mathrm{L}, 810 \mathrm{mg}, 2.94 \mathrm{mmol}, 1.20\right.$ equiv.). The mixture was cooled to $0^{\circ} \mathrm{C}$ for $5 \mathrm{mins}$ and DBU $(440 \mu \mathrm{L}, 448 \mathrm{mg}, 2.94 \mathrm{mmol}, 1.20$ equiv.) added. The reaction mixture was allowed to warm to room temperature and stirred for $18 \mathrm{~h}$. The reaction was subsequently quenched with water $(10 \mathrm{~mL})$ and aq. $\mathrm{HCl}$ $5 \% \mathrm{v} / \mathrm{v}(10 \mathrm{~mL})$ and extracted with EtOAc $(2 \times 10 \mathrm{~mL})$. The combined organic fractions were dried over $\mathrm{MgSO}_{4}$ and concentrated under reduced pressure, the crude reside was purified by flash column chromatography (20:1 hexane/EtOAc). 


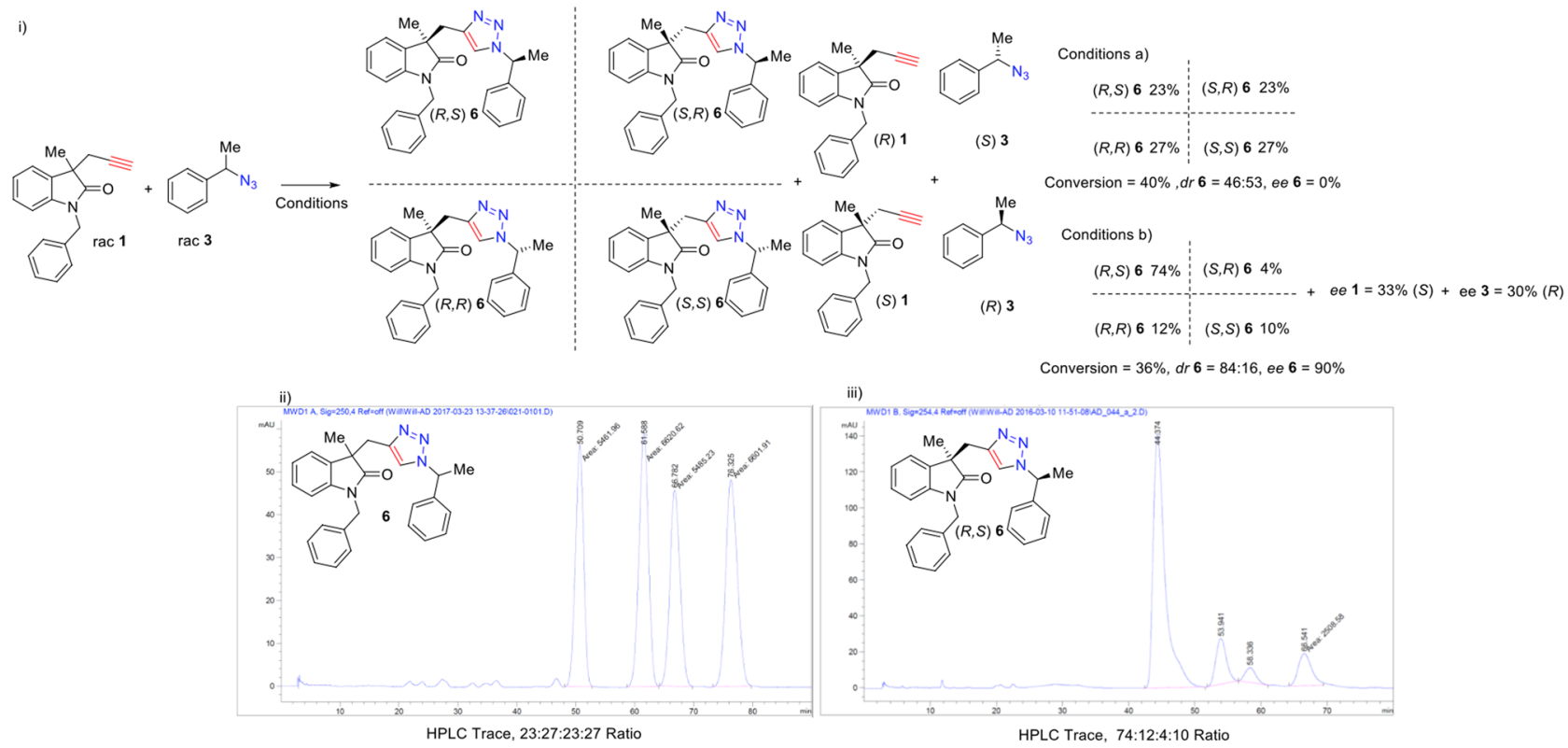

Scheme 3. (i) Coetaneous Kinetic Resolution of Azides and Alkynes. Conversion was determined by ${ }^{1} \mathrm{H}$ NMR spectroscopy. Enantioenrichment of $\mathbf{6}$ and $\mathbf{1}$ was determined by HPLC using a chiral stationary phase. "Stereochemical nomenclature to describe diastereoisomers as follows: The first letter inside the brackets refers to the stereochemical descriptor at the oxindole stereogenic centre, the second letter within the brackets refers to stereochemical descriptor at the stereogenic centre adjacent to the triazole ring". Enantioenrichment of azide 3 was determined by GC using a chiral stationary phase. (ii) HPLC trace of outcomes using conditions: (a) Alkyne 1 ( 1 equiv.) to azide 3 ( 1 equiv.), TBTA (15.0 mol\%), $\mathrm{CuCl}(12.5 \mathrm{~mol} \%)$ in 2,5 -hexanedione at $0^{\circ} \mathrm{C}$ for $96 \mathrm{~h}$. (iii) HPLC trace using conditions; or (b) Alkyne $\mathbf{1}$ (1 equiv.) to azide 3 (1 equiv.), $\mathrm{CuCl}$ ( $12.5 \mathrm{~mol} \%), \mathbf{L 1}$ $(15.0 \mathrm{~mol} \%)$ in 2,5 -hexanedione at $0^{\circ} \mathrm{C}$ for $96 \mathrm{~h}$.

\begin{tabular}{|l|l|l|l|l|l|}
\hline & \\
\hline
\end{tabular}

Table 2. Kinetic resolution with enantiopure partners. Reactions were run with 0.5 equiv. of single enantiomer substrate to 1 equiv. of racemic substrate. ${ }^{a}$ Enantiopure alkyne 1 was obtained by preparative chiral HPLC (see ESI). ${ }^{b}$ Enantiopure azide 3 was synthesised according to literature procedure (see ESI). ${ }^{c}$ Conversion was determined by integration of ${ }^{1} \mathrm{H}$ NMR spectra (see ESI). ${ }^{\mathrm{d}} \mathrm{SM}$ refers to the recovered alkyne/azide following resolution ( rac component before resolution).

(S)-(1-Azidoethyl)benzene (3 (S)). Prepared from $(R)$-phenylethanol according to general procedure, colourless oil 3 (S) (131 mg, 35\%). ${ }^{1} \mathrm{H}$ NMR $\left(300 \mathrm{MHz}, \mathrm{CDCl}_{3}\right) \delta 7.50-6.97$ (m, 5H, Ar-H), 4.57 (q, J 6.8, 1H, CH), 1.49 (d, J 6.8, 3H, $\left.\mathrm{CH}_{3}\right) ;{ }^{13} \mathrm{C} \mathrm{NMR}\left(101 \mathrm{MHz}, \mathrm{CDCl}_{3}\right) \delta 140.90,128.80,128.14,126.41,61.12,21.80 ; \mathrm{MS} \mathrm{ESI}^{+} \mathrm{m} / z$ $147.1[\mathrm{M}]^{+}, 105.1\left[\mathrm{M}-\mathrm{N}_{3}\right]^{+}, 77.0\left[\mathrm{M}-\mathrm{C}_{2} \mathrm{H}_{4} \mathrm{~N}_{3}\right]^{+}$; GC (CP-Chirasil-Dex CB), FID, $\mathrm{t}=28.1 \mathrm{~min}$.

$(R)$-(1-Azidoethyl)benzene (3 $(R))$. Prepared from $(S)$-phenylethanol according to the general procedure, colourless oil $3(R)\left(150 \mathrm{mg}, 40 \%\right.$ yield). ${ }^{1} \mathrm{H}$ NMR $\left(300 \mathrm{MHz}, \mathrm{CDCl}_{3}\right) \delta 7.42-7.18(\mathrm{~m}, 5 \mathrm{H}, \mathrm{Ar}-H), 4.56(\mathrm{q}, J 6.8,1 \mathrm{H}$, $\mathrm{CH}), 1.48\left(\mathrm{~d}, J=6.8,3 \mathrm{H}, \mathrm{CH}_{3}\right) ;{ }^{13} \mathrm{C} \mathrm{NMR}\left(101 \mathrm{MHz}, \mathrm{CDCl}_{3}\right) \delta 140.90,128.80,128.16,126.41,61.12$, 21.58; MS $\mathrm{ESI}^{+} \mathrm{m} / z$ 147.1 $[\mathrm{M}]^{+}, 105.1\left[\mathrm{M}-\mathrm{N}_{3}\right]^{+}, 77.0\left[\mathrm{M}-\mathrm{C}_{2} \mathrm{H}_{4} \mathrm{~N}_{3}\right]^{+}$; GC (CP-Chirasil-Dex CB), FID, $\mathrm{t}=28.4 \mathrm{~min}$. 
Synthesis of racemic 4-phenyl-1-(1-phenylethyl)-1H-1,2,3-triazole (5). Phenylacetylene (20.0 mg, $0.20 \mathrm{mmol}, 1.00$ equiv.), (1-azidoethyl)benzene $3(30.0 \mathrm{mg}, 0.20 \mathrm{mmol}, 1.00$ equiv.) and sodium ascorbate (39.0 mg, $0.20 \mathrm{mmol}, 1.00$ equiv.) were added to a solution of $\mathrm{CuSO}_{4} \| 5 \mathrm{H}_{2} \mathrm{O}(5.00 \mathrm{mg}, 0.020 \mathrm{mmol}, 10 \mathrm{~mol} \%)$ in $\mathrm{MeOH}(4 \mathrm{~mL})$. The reaction mixture was allowed to stir for $24 \mathrm{~h}$ at $\mathrm{rt}$. The reaction was quenched with aq. ammonia solution $5 \% \mathrm{v} / \mathrm{v}(5 \mathrm{~mL})$ and extracted with EtOAc $(2 \times 10 \mathrm{~mL})$. The combined organic extracts were dried over $\mathrm{MgSO}_{4}$ and concentrated under reduced pressure to yield 4-phenyl-1-(1-phenylethyl)-1 $\mathrm{H}-1,2,3$-triazole 5 as a cream solid (13.0 mg, 26\%). Characterisation was consistent with reported literature values ${ }^{41} .{ }^{1} \mathrm{H} \mathrm{NMR}(300 \mathrm{MHz}$, $\mathrm{CDCl}_{3}$ 8 7.76-7.82 (m, 2H, Ar-H), 7.64 (s, 1H, CH), 7.26-7.45 (m, 8H, Ar- H), $5.86(\mathrm{q}, J 7.1,1 \mathrm{H}, \mathrm{CH}),, 2.02(\mathrm{~d}$, J 7.1, 3H, $\left.\mathrm{CH}_{3}\right) ;{ }^{13} \mathrm{C}$ NMR $\left(101 \mathrm{MHz}, \mathrm{CDCl}_{3}\right) \delta 147.80,139.92,130.67,129.07,128.79,128.58,128.10,126.55$, 125.69, 118.40, 60.29, 21.32; IR $\nu_{\max }($ ATR $) / \mathrm{cm}^{-1} 3090,2991 ; \mathrm{MS} \mathrm{ESI}^{+} \mathrm{m} / z 272.1[\mathrm{M}+\mathrm{Na}]^{+}, 250.1[\mathrm{M}+\mathrm{H}]^{+}$; HPLC (Phenomenex Cellulose 1) acetonitrile/water 60:40, $1.0 \mathrm{~mL} / \mathrm{min}, \lambda=210 \mathrm{~nm}, \mathrm{t}=8.4$ and $9.1 \mathrm{~min}$.

Synthesis of 1-benzyl-3-methyl-3-((1-(1-phenylethyl)-1H-1,2,3-triazol-4-yl)methyl)indolin2-one (6). To a solution of 1-benzyl-3-methyl-3-(prop-2-yn-1-yl)indolin-2-one $\mathbf{1}(100 \mathrm{mg}, 0.36 \mathrm{mmol}$, 1 equiv.) in acetone $(5 \mathrm{~mL})$ was added copper (I) chloride $(1.80 \mathrm{mg}, 0.018 \mathrm{mmol}, 5 \mathrm{~mol} \%)$, TBTA $(9.60 \mathrm{mg}$, $0.018 \mathrm{mmol}, 5 \mathrm{~mol} \%)$ and (1-azidoethyl)benzene $3(60.0 \mathrm{mg}, 0.40 \mathrm{mmol}, 1.10$ equiv.) in acetone ( $1 \mathrm{~mL})$. The mixture was heated to reflux and stirred for $96 \mathrm{~h}$. The reaction mixture was then quenched with aq. ammonia $5 \% \mathrm{v} / \mathrm{v}(5 \mathrm{~mL})$ and extracted with EtOAc $(3 \times 10 \mathrm{~mL})$. The combined organic extracts were washed with water $(10 \mathrm{~mL})$, died over $\mathrm{MgSO}_{4}$ and concentrated under reduced pressure. The crude residue was purified by automated flash column chromatography Combiflash Rf (0-100\% hexane/EtOAc, 12 mins) to yield the triazole 6 as a colourless oil $\left(65.0 \mathrm{mg}, 42 \%\right.$ yield). Reported as a mixture of diastereoisomers. ${ }^{1} \mathrm{H}$ NMR $\left(400 \mathrm{MHz}, \mathrm{CDCl}_{3}\right) \delta$ 7.32-7.19 (m, 12H (residual solvent ignored), Ar-H), 7.15-7.02 (m, 8H, Ar- $H$ ), 7.00-6.88 (m, 6H, Ar-H), 6.72 $(\mathrm{s}, 1 \mathrm{H}$, Triazole $\mathrm{CH}), 6.68(\mathrm{~s}, 1 \mathrm{H}$, Triazole $\mathrm{CH}), 6.56-6.48(\mathrm{~m}, 2 \mathrm{H}, \mathrm{Ar}-H), 5.54-5.62(\mathrm{~m}, 2 \mathrm{H}, \mathrm{CH}), 4.55-4.76(\mathrm{~m}$, $\left.4 \mathrm{H}, \mathrm{CH}_{2}\right), 3.16-3.38\left(\mathrm{~m}, 4 \mathrm{H}, \mathrm{CH}_{2}\right), 1.79\left(\mathrm{~d}, J 7.1,3 \mathrm{H}, \mathrm{CH}_{3}\right), 1.69\left(\mathrm{~d}, J 7.1,3 \mathrm{H}, \mathrm{CH}_{3}\right), 1.52\left(\mathrm{~s}, 3 \mathrm{H}, \mathrm{CH}_{3}\right), 1.51(\mathrm{~s}$, $\left.3 \mathrm{H}, \mathrm{CH}_{3}\right) ;{ }^{13} \mathrm{C}$ NMR $\left(101 \mathrm{MHz}, \mathrm{CDCl}_{3}\right) \delta 179.93,142.97,142.88,142.17,140.24,140.19,135.97,135.86,132.97$, $128.86,128.71,128.20,128.16,127.80,127.51,127.48,127.29,127.19,126.20,126.17,123.30,123.22,122.52$, $122.45,120.80,120.39,108.85,108.77,59.78,59.56,48.57,48.54,43.51,34.49,34.45,23.32,21.17,20.81$; IR $v_{\max }$ (ATR) $/ \mathrm{cm}^{-1} 3032,2968,2925,1705,1610 ; \mathrm{MS} \mathrm{ESI}^{+} \mathrm{m} / z$ 445.2 $[\mathrm{M}+\mathrm{Na}]^{+}, 423.2[\mathrm{M}+\mathrm{H}]^{+} ; \mathrm{HRMS} \mathrm{ESI}^{+}$ Calculated for $\mathrm{C}_{27} \mathrm{H}_{26} \mathrm{~N}_{4} \mathrm{ONa}^{+}=445.1999$ Found 445.2007; HPLC (Cellulose 3) acetonitrile/water 30:70, $1.0 \mathrm{~mL} /$ $\min , \lambda=210 \mathrm{~nm}, 45 \mathrm{~min}, 55 \mathrm{~min}, 59 \mathrm{~min}, 67 \mathrm{~min}$.

Synthesis of (R)-1-benzyl-3-methyl-3-((1-((S)-1-phenylethyl)-1H-1,2,3-triazol-4-yl)methyl) indolin-2-one $(6(R, S))$. To a solution of $(R)$-1-benzyl-3-methyl-3-(prop-2-yn-1-yl)indolin-2-one $\mathbf{1}(\boldsymbol{R})$ (30.0 mg, $0.11 \mathrm{mmol}, 1.00$ equiv.) in methanol $(5 \mathrm{~mL})$ was added $(S)$-(1-azidoethyl)benzene $3(S)$ (16.0 mg, $0.11 \mathrm{mmol}, 1.00$ equiv.), $\mathrm{CuSO}_{4} \| 5 \mathrm{H}_{2} \mathrm{O}(3.00 \mathrm{mg}, 0.011 \mathrm{mmol}, 10 \mathrm{~mol} \%)$ and sodium ascorbate $(5.00 \mathrm{mg}$, $0.022 \mathrm{mmol}, 20 \mathrm{~mol} \%)$. The reaction was stirred at $50^{\circ} \mathrm{C}$ for $24 \mathrm{~h}$. After this time the reaction was quenched with the addition of aq. ammonia solution $5 \% \mathrm{v} / \mathrm{v}(5 \mathrm{~mL})$, the reaction was then extracted with EtOAc $(2 \times 10 \mathrm{~mL})$. The combined organic fractions were dried over $\mathrm{MgSO}_{4}$ and concentrated under reduced pressure. The crude residue was purified by automated flash column chromatography Combiflash $\mathrm{Rf}(0-100 \%$ EtOAc/hexane gradient, 15 mins). This yielded $(R)$-1-benzyl-3-methyl-3-((1-((S)-1-phenylethyl)-1H-1,2,3-triazol-4-yl)methyl)indolin2-one $\mathbf{6}(\boldsymbol{R}, \boldsymbol{S})$ as a yellow oil $(29.0 \mathrm{mg}, 62 \%) .{ }^{1} \mathrm{H}$ NMR $\left(400 \mathrm{MHz}^{\mathrm{CDCl}}{ }_{3}\right) \delta 7.29-7.18(\mathrm{~m}, 6 \mathrm{H}, \mathrm{Ar}-\mathrm{H}), 7.14-7.07$ (m, 3H, Ar-H), $7.04(\mathrm{td}, J 7.7,1.3,1 \mathrm{H}, \mathrm{Ar}-H), 6.97-6.89(\mathrm{~m}, 3 \mathrm{H}, \mathrm{Ar}-\mathrm{H}), 6.72(\mathrm{~s}, 1 \mathrm{H}$, Triazole CH), $6.50(\mathrm{~d}, J 7.7,1 \mathrm{H}$, Ar- $H$ ), $5.57(\mathrm{q}, J 7.1,1 \mathrm{H}, \mathrm{CH}), 4.65\left(\mathrm{ABq}, \Delta \delta_{\mathrm{AB}}=0.14, J 15.6,2 \mathrm{H}, \mathrm{CH}_{2}\right), 3.27\left(\mathrm{ABq}, \Delta \delta_{\mathrm{AB}}=0.14, J 14.3,2 \mathrm{H}, \mathrm{CH}_{2}\right)$, $1.79\left(\mathrm{~d}, J 7.1,3 \mathrm{H}, \mathrm{CH}_{3}\right), 1.51\left(\mathrm{~s}, 3 \mathrm{H}, \mathrm{CH}_{3}\right) ;{ }^{13} \mathrm{C}$ NMR $\left(101 \mathrm{MHz}, \mathrm{CDCl}_{3}\right) \delta 179.92,142.88,142.16,140.25,135.91$, $132.98,128.85,128.70,128.15,127.79,127.48,127.19,126.16,123.22,122.44,120.80,108.84,59.78,48.53,43.50$, 34.45, 23.32, 21.16; MS AP ${ }^{+} m / z$ 423.2 [M+H] $]^{+}$; $\mathrm{HRMS} \mathrm{AP}^{+}$Calculated for $\mathrm{C}_{27} \mathrm{H}_{27} \mathrm{~N}_{4} \mathrm{O}^{+}=423.2179$ Found 423.2187; IR $v_{\max }$ (ATR)/ $\mathrm{cm}^{-1} 2925,2855,1707,1489,1467,1356,1174,855,741,698$; HPLC (Phenomenex Cellulose 3) acetonitrile/water $30: 70,1.0 \mathrm{~mL} / \mathrm{min}, \lambda=250 \mathrm{~nm}, \mathrm{t}=49$ mins.

Synthesis of 1-benzyl-3-methyl-3-(1-((S)-1-phenylethyl)-1H-1,2,3-triazol-4-yl)indolin-2-one (6 (rac-S)). Compound 3 ( $85.0 \mathrm{mg}, 0.31 \mathrm{mmol}, 1.00$ equiv.) and $\mathbf{1}(S)(50.0 \mathrm{mg}, 0.34 \mathrm{mmol}, 1.10$ equiv.) were dissolved in $\mathrm{MeOH}(5 \mathrm{~mL})$. To this solution was added $\mathrm{CuSO}_{4} .5 \mathrm{H}_{2} \mathrm{O}(7.70 \mathrm{mg}, 0.031 \mathrm{mmol}, 10 \mathrm{~mol} \%)$ and sodium ascorbate $(61.0 \mathrm{mg}, 0.31 \mathrm{mmol}, 1.00$ equiv.) and the resulting mixture stirred for $5 \mathrm{mins}$ at rt. After this time $\mathrm{N}, \mathrm{N}$-diisoproylethylamine $(100 \mu \mathrm{L}, 7.40 \mathrm{mg}, 5 \mathrm{~mol} \%)$ was added and the mixture left to stir at $\mathrm{rt}$ for $48 \mathrm{~h}$. The reaction mixture was then quenched by the addition of aqueous ammonia solution $5 \% \mathrm{v} / \mathrm{v}(5 \mathrm{~mL})$. The resulting solution was extracted with EtOAc $(3 \times 10 \mathrm{~mL})$. The combined organic fractions were washed with water $(10 \mathrm{~mL})$ dried over $\mathrm{MgSO}_{4}$ and concentrated under reduced pressure. The recovered crude material was purified by automated flash column chromatography Combiflash $\mathrm{Rf}(0-100 \%$ hexane/EtOAc gradient 12 mins). This yielded 1-benzyl-3-methyl-3-(1-((S)-1-phenylethyl)-1H-1,2,3-triazol-4-yl)indolin-2-one 6 ( rac,$S)$ as a colourless oil (72.0 mg, 57\% yield). The ${ }^{1} \mathrm{H}$ NMR spectrum of the product was consistent with compound 6 . HPLC (Phenomenex Cellulose 3) acetonitrile/water 30:70, $1.0 \mathrm{~mL} / \mathrm{min}, \lambda=210 \mathrm{~nm}, 45 \mathrm{~min}, 67 \mathrm{~min}$.

\section{Catalysis}

Representative procedure for kinetic resolution of (1-Azidoethyl)benzene (3). To an oven dried Radley's multi-reactor tube were added $\mathbf{L} 1$ ( $6.70 \mathrm{mg}, 0.018 \mathrm{mmol}, 15.0 \mathrm{~mol} \%), \mathrm{CuCl}(1.50 \mathrm{mg}, 0.015 \mathrm{mmol}$, $12.5 \mathrm{~mol} \%$ ) and 2,5-hexanedione $(1 \mathrm{~mL})$, these were stirred together at $\mathrm{rt}$ for $1 \mathrm{~h}$. To this solution was added phenylacetylene $(6.20 \mathrm{mg}, 0.06 \mathrm{mmol}, 0.50$ equiv.) in 2,5 -hexanedione $(0.5 \mathrm{~mL})$ and the resulting mixture stirred for $15 \mathrm{mins}$ at $\mathrm{rt}$ before being cooled to $0^{\circ} \mathrm{C}$ and stirred for a further $15 \mathrm{mins}$. (1-azidoethyl)benzene $3(17.8 \mathrm{mg}$, $0.12 \mathrm{mmol}, 1.00$ equiv.) in 2,5 -hexanedione $(0.5 \mathrm{~mL})$ was then added and the reaction mixture stirred for $96 \mathrm{~h}$ 
at $0{ }^{\circ} \mathrm{C}$. The reaction mixture was then quenched with the addition of aq. ammonia solution $5 \% \mathrm{v} / \mathrm{v}(5 \mathrm{~mL})$ then extracted with ether $(2 \times 10 \mathrm{~mL})$. The combined organic extracts were dried over $\mathrm{MgSO}_{4}$ and concentrated under reduced pressure. Conversion of the reaction was determined through ${ }^{1} \mathrm{H}$ NMR spectroscopy of the recovered crude material. Enantiomeric excess was determined by chiral GC. The remaining azide and triazolic product were isolated by automated flash column chromatography Combiflash $\mathrm{Rf}$ ( $0-40 \%$ hexane/EtOAc, $15 \mathrm{mins})$.

General procedure for the kinetic resolution of $\mathbf{1}$ with Azide 3. To an oven dried Radley's multi-reactor tube $\mathbf{L 1}(6.70 \mathrm{mg}, 0.018 \mathrm{mmol}, 15.0 \mathrm{~mol} \%)$ and $\mathrm{CuCl}(1.50 \mathrm{mg}, 0.015 \mathrm{mmol}, 12.5 \mathrm{~mol} \%)$ followed by 2,5-hexanedione ( $1 \mathrm{~mL}$ ) were added. After stirring at $\mathrm{rt}$ for $1 \mathrm{~h}$, compound $\mathbf{1}(33.4 \mathrm{mg}, 0.12 \mathrm{mmol}, 1$ equiv.) dissolved in 2,5-hexanedione $(0.5 \mathrm{~mL})$ was added. The reaction mixture was stirred for a further 15 mins before being cooled to $0^{\circ} \mathrm{C}$ for $15 \mathrm{~min}$. Azide $3(\boldsymbol{R})(8.90 \mathrm{mg}, 0.06 \mathrm{mmol}, 1$ equiv.) dissolved in 2,5-hexanedione $(0.5 \mathrm{~mL})$ was then added. The reaction mixture was stirred at $0{ }^{\circ} \mathrm{C}$ for $96 \mathrm{~h}$. The reaction was then quenched by addition of aqueous ammonia $5 \% \mathrm{v} / \mathrm{v}(5 \mathrm{~mL})$. The reaction mixture was then extracted with ethyl acetate $(2 \times 10 \mathrm{~mL})$, dried over $\mathrm{MgSO}_{4}$ and concentrated under reduced pressure. Conversion was determined by integration of the ${ }^{1} \mathrm{H}$ NMR spectrum of the recovered material. The remaining starting material and the triazolic product were subsequently isolated by automated column chromatography Combiflash $\mathrm{Rf}(0-100 \%$ hexane/EtOAc gradient 12 mins). Enantiomeric excess and diastereomer ratio of $\mathbf{6}$ and enantiomeric excess of $\mathbf{1}$ were determined by chiral HPLC.

General procedure for the kinetic resolution of $\mathbf{3}$ with Alkyne $1 . \quad$ To an oven dried Radley's multi-reactor tube was added $\mathbf{L 1}(6.70 \mathrm{mg}, 0.018 \mathrm{mmol}, 15.0 \mathrm{~mol} \%)$ and $\mathrm{CuCl}(1.50 \mathrm{mg}, 0.015 \mathrm{mmol}, 12.5 \mathrm{~mol} \%)$ followed by 2,5 -hexanedione $(1 \mathrm{~mL})$, the resulting solution was allowed to stir at $\mathrm{rt}$ for $1 \mathrm{~h}$. After this time compound 1 ( $16.7 \mathrm{mg}, 0.06 \mathrm{mmol}, 0.5$ equiv.) dissolved in 2,5 -hexanedione $(0.5 \mathrm{~mL})$ was added. The reaction mixture was allowed to stir at $\mathrm{rt}$ for a further $15 \mathrm{mins}$ after which it was cooled to $0{ }^{\circ} \mathrm{C}$ in an ice bath and stirred for a subsequent $15 \mathrm{mins}$. After this time had passed azide $3(17.8 \mathrm{mg}, 0.12 \mathrm{mmol}, 1$ equiv.) dissolved in 2,5-hexanedione $(0.5 \mathrm{~mL})$ was added. The reaction mixture was stirred for $96 \mathrm{~h}$ at $0{ }^{\circ} \mathrm{C}$ before being quenched by the addition of aqueous ammonia $5 \% \mathrm{v} / \mathrm{v}(5 \mathrm{~mL})$. The resulting solution was extracted with EtOAc $(2 \times 10 \mathrm{~mL})$, the combined organic fractions were dried over $\mathrm{MgSO}_{4}$ and concentrated under reduced pressure. Chiral GC was carried out on the crude recovered material to measure the $e e$ of the remaining azide 3 . The remaining crude material was the purified by automated flash column chromatography Combiflash Rf ( $0-100 \%$ hexane/EtOAc gradient, 12 mins). The $d r$ and $e e$ of the triazolic product was then determined by chiral HPLC.

General procedure for simultaneous kinetic resolution of 1 and 3. To an oven dried Radley's multi-reactor tube was added $\mathbf{L} \mathbf{1}(6.70 \mathrm{mg}, 0.018 \mathrm{mmol}, 15.0 \mathrm{~mol} \%)$ and $\mathrm{CuCl}(1.50 \mathrm{mg}, 0.015 \mathrm{mmol}, 12.5 \mathrm{~mol} \%)$ followed by 2,5-hexanedione $(1 \mathrm{~mL})$, the resulting solution was allowed to stir at $\mathrm{rt}$ for $1 \mathrm{~h}$. After this time compound 1 ( $33.4 \mathrm{mg}, 0.12 \mathrm{mmol}, 1.00$ equiv.) dissolved in 2,5 -hexanedione $(0.5 \mathrm{~mL})$ was added. The reaction mixture was allowed to stir at $\mathrm{rt}$ for a further $15 \mathrm{mins}$ after which it was cooled to $0{ }^{\circ} \mathrm{C}$ in an ice bath and stirred for a subsequent 15 mins. After this time had passed azide 3 ( $17.8 \mathrm{mg}, 0.12 \mathrm{mmol}, 1$ equiv.) dissolved in 2,5-hexanedione $(0.5 \mathrm{~mL})$ was added. The reaction mixture was stirred for $96 \mathrm{~h}$ at $0{ }^{\circ} \mathrm{C}$ before being quenched by the addition of aqueous ammonia $5 \% \mathrm{v} / \mathrm{v}(5 \mathrm{~mL})$. The resulting solution was extracted with EtOAc $(2 \times 10 \mathrm{~mL})$, the combined organic fractions were dried over $\mathrm{MgSO}_{4}$ and concentrated under reduced pressure. Chiral GC was carried out on the crude recovered material to measure the ee of the remaining azide 3 . The remaining crude material was the purified by automated flash column chromatography Combiflash $\mathrm{Rf}(0-100 \%$ hexane/EtOAc gradient, 12 mins). The $d r$ and $e e$ of the triazolic product $\mathbf{6}$ and $e e$ of the recovered alkyne $\mathbf{1}$ was then determined by HPLC with a chiral stationary phase.

Supplementary information is available that includes detailed experimental procedures, NMR spectrums, HPLC traces and X-ray crystallographic information. Citations therein should be referred to in relation to published procedures ${ }^{40-44}$ and a pre-peer reviewed preprint was submitted prior to peer assessment of this manuscript ${ }^{45}$.

Received: 17 July 2019; Accepted: 18 September 2019;

Published online: 21 October 2019

\section{References}

1. Lewis, W. G. et al. Click Chemistry In Situ: Acetylcholinesterase as a Reaction Vessel for the Selective Assembly of a Femtomolar Inhibitor from an Array of Building Blocks. Angew. Chem. Int. Ed. 41, 1053-1057, 10.1002/1521-3773(20020315)41:6<1053::AIDANIE1053>3.0.CO;2-4 (2002).

2. Tornøe, C. W., Christensen, C. \& Meldal, M. Peptidotriazoles on Solid Phase: [1,2,3]-Triazoles by Regiospecific Copper(I)-Catalyzed 1,3-Dipolar Cycloadditions of Terminal Alkynes to Azides. J. Org. Chem. 67, 3057-3064, https://doi.org/10.1021/jo011148j (2002).

3. Kolb, H. C., Finn, M. G. \& Sharpless, K. B. Click Chemistry: Diverse Chemical Function from a Few Good Reactions. Angew. Chem. Int. Ed. Engl. 40, 2004-2021 (2001).

4. Meldal, M. \& Tornøe, C. W. Cu-Catalyzed Azide-Alkyne Cycloaddition. Chem. Rev. 108, 2952-3015, https://doi.org/10.1021/ cr0783479 (2008).

5. Thirumurugan, P., Matosiuk, D. \& Jozwiak, K. Click Chemistry for Drug Development and Diverse Chemical-Biology Applications. Chem. Rev. 113, 4905-4979, https://doi.org/10.1021/cr200409f (2013).

6. Amblard, F., Cho, J. H. \& Schinazi, R. F. Cu(I)-Catalyzed Huisgen Azide-Alkyne 1,3-Dipolar Cycloaddition Reaction in Nucleoside, Nucleotide, and Oligonucleotide Chemistry. Chem. Rev. 109, 4207-4220, https://doi.org/10.1021/cr9001462 (2009).

7. Chinchilla, R. \& Nájera, C. Chemicals from Alkynes with Palladium Catalysts. Chem. Rev. 114, 1783-1826, https://doi.org/10.1021/ cr400133p (2014).

8. El-Sagheer, A. H. \& Brown, T. Click chemistry with DNA. Chem. Soc. Rev. 39, 1388-1405, https://doi.org/10.1039/B901971P (2010). 
9. Moses, J. E. \& Moorhouse, A. D. The growing applications of click chemistry. Chem. Soc. Rev. 36, 1249-1262, https://doi.org/10.1039/ b613014n (2007).

10. Jinks, M. A. et al. Stereoselective Synthesis of Mechanically Planar Chiral Rotaxanes. Angew. Chem. 130, 15022-15026, https://doi. org/10.1002/ange.201808990 (2018).

11. Kagan, H. B. \& Fiaud, J. C. In Topics in Stereochemistry (eds E. L. Eliel \& S. H. Wilen) 249-330 (John Wiley \& Sons, Inc., 2007).

12. Schofer, S. H., Kaftzik, N., Wasserscheid, P. \& Kragl, U. Enzyme catalysis in ionic liquids: lipase catalysed kinetic resolution of 1-phenylethanol with improved enantioselectivity. Chem. Commun., 425-426, https://doi.org/10.1039/B009389K (2001).

13. Ghanem, A. \& Aboul-Enein, H. Y. Application of lipases in kinetic resolution of racemates. Chirality 17, 1-15, https://doi. org/10.1002/chir.20089 (2005).

14. Arai, S., Bellemin-Laponnaz, S. \& Fu, G. C. Kinetic Resolution of Amines by a Nonenzymatic Acylation Catalyst. Angew. Chem. Int. Ed. 40, 234-236, 10.1002/1521-3773(20010105)40:1<234::AID-ANIE234>3.0.CO;2-K (2001).

15. Ruble, J. C., Latham, H. A. \& Fu, G. C. Effective Kinetic Resolution of Secondary Alcohols with a Planar-Chiral Analogue of 4-(Dimethylamino)pyridine. Use of the $\mathrm{Fe}\left(\mathrm{C}_{5} \mathrm{Ph}_{5}\right)$ Group in Asymmetric Catalysis. J. Am. Chem. Soc. 119, 1492-1493, https://doi. org/10.1021/ja963835b (1997).

16. Fu, G. C. Asymmetric Catalysis with "Planar-Chiral” Derivatives of 4-(Dimethylamino)pyridine. Acc. Chem. Res. 37, 542-547, https://doi.org/10.1021/ar030051b (2004).

17. Brittain, W. D. G. et al. The Bull-James assembly as a chiral auxiliary and shift reagent in kinetic resolution of alkyne amines by the CuAAC reaction. Org. Biomol. Chem. 14, 10778-10782, https://doi.org/10.1039/C6OB01623E (2016).

18. Brittain, W. D. G., Buckley, B. R. \& Fossey, J. S. Asymmetric Copper-Catalyzed Azide-Alkyne Cycloadditions. ACS Catal 6, 3629-3636, https://doi.org/10.1021/acscatal.6b00996 (2016).

19. Brittain, W. D. G., Buckley, B. R. \& Fossey, J. S. Kinetic resolution of alkyne-substituted quaternary oxindoles via copper catalysed azide-alkyne cycloadditions. Chem. Commun. 51, 17217-17220, https://doi.org/10.1039/C5CC04886A (2015).

20. Meng, J.-c, Fokin, V. V. \& Finn, M. G. Kinetic resolution by copper-catalyzed azide-alkyne cycloaddition. Tetrahedron Lett. 46, 4543-4546, https://doi.org/10.1016/j.tetlet.2005.05.019 (2005).

21. Alexander, J. R., Ott, A. A., Liu, E.-C. \& Topczewski, J. J. Kinetic Resolution of Cyclic Secondary Azides, Using an Enantioselective Copper-Catalyzed Azide-Alkyne Cycloaddition. Org. Lett. 21, 4355-4358, https://doi.org/10.1021/acs.orglett.9b01556 (2019).

22. Liu, E.-C. \& Topczewski, J. J. Enantioselective Copper Catalyzed Alkyne-Azide Cycloaddition by Dynamic Kinetic Resolution. J. Am. Chem. Soc. 141, 5135-5138, https://doi.org/10.1021/jacs.9b01091 (2019).

23. Chen, M.-Y. et al. Catalytic Asymmetric Huisgen Alkyne-Azide Cycloaddition of Bisalkynes by Copper(I) Nanoparticles. ChemCatChem 10, 280-286, https://doi.org/10.1002/cctc.201701336 (2018).

24. Chen, M.-Y. et al. Tao-Phos-controlled desymmetrization of succinimide-based bisalkynes via asymmetric copper-catalyzed Huisgen alkyne-azide click cycloaddition: substrate scope and mechanism. Rsc Adv 6, 58698-58708, https://doi.org/10.1039/ C6RA13687G (2016).

25. Zhou, F. et al. Asymmetric Copper(I)-Catalyzed Azide-Alkyne Cycloaddition to Quaternary Oxindoles. J. Am. Chem. Soc. 135, 10994-10997, https://doi.org/10.1021/ja4066656 (2013).

26. Vedejs, E. \& Chen, X. Parallel Kinetic Resolution. J. Am. Chem. Soc. 119, 2584-2585, https://doi.org/10.1021/ja963666v (1997).

27. Miller, L. C., Ndungu, J. M. \& Sarpong, R. Parallel Kinetic Resolution Approach to the Cyathane and Cyanthiwigin Diterpenes Using a Cyclopropanation/Cope Rearrangement. Angew. Chem. Int. Ed. 48, 2398-2402, https://doi.org/10.1002/anie.200806154 (2009).

28. Kato, K., Motodate, S., Takaishi, S., Kusakabe, T. \& Akita, H. Parallel kinetic resolution of propargyl ketols: formal synthesis of (+)-bakkenolide A. Tetrahedron 64, 4627-4636, https://doi.org/10.1016/j.tet.2008.02.101 (2008).

29. Kreituss, I. \& Bode, J. W. Flow chemistry and polymer-supported pseudoenantiomeric acylating agents enable parallel kinetic resolution of chiral saturated N-heterocycles. Nat. Chem 9, 446-452, https://doi.org/10.1038/Nchem.2681 (2017).

30. Tanaka, K. \& Fu, G. C. Parallel Kinetic Resolution of 4-Alkynals Catalyzed by Rh(I)/Tol-BINAP: Synthesis of Enantioenriched Cyclobutanones and Cyclopentenones. J. Am. Chem. Soc. 125, 8078-8079, https://doi.org/10.1021/ja0354891 (2003).

31. Krautwald, S. \& Carreira, E. M. Stereodivergence in Asymmetric Catalysis. J. Am. Chem. Soc. 139, 5627-5639, https://doi. org/10.1021/jacs.6b13340 (2017).

32. Krautwald, S., Sarlah, D., Schafroth, M. A. \& Carreira, E. M. Enantio- and Diastereodivergent Dual Catalysis: $\alpha$-Allylation of Branched Aldehydes. Science 340, 1065-1068, https://doi.org/10.1126/science.1237068 (2013).

33. Osako, T. \& Uozumi, Y. Enantioposition-Selective Copper-Catalyzed Azide-Alkyne Cycloaddition for Construction of Chiral Biaryl Derivatives. Org. Lett. 16, 5866-5869, https://doi.org/10.1021/ol502778j (2014).

34. Osako, T. \& Uozumi, Y. Mechanistic Insights into Copper-Catalyzed Azide-Alkyne Cycloaddition (CuAAC): Observation of Asymmetric Amplification. Synlett 26, 1475-1479, https://doi.org/10.1055/s-0034-1380534 (2015).

35. Abbadie, C. et al. Analgesic effects of a substituted N-triazole oxindole (TROX-1), a state-dependent, voltage-gated calcium channel 2 blocker. J. Pharmacol. Exp. Ther. 334, 545-555, https://doi.org/10.1124/jpet.110.166363 (2010).

36. Laird, A. D. et al. SU6668 Is a Potent Antiangiogenic and Antitumor Agent That Induces Regression of Established Tumors. Cancer Res. 60, 4152-4160 (2000).

37. Galliford, C. V. \& Scheidt, K. A. Pyrrolidinyl-Spirooxindole Natural Products as Inspirations for the Development of Potential Therapeutic Agents. Angew. Chem. Int. Ed. 46, 8748-8758, https://doi.org/10.1002/anie.200701342 (2007).

38. Kamano, Y. et al. Convolutamydine A, a novel bioactive hydroxyoxindole alkaloid from marine bryozoan Amathia convoluta. Tetrahedron Lett. 36, 2783-2784, https://doi.org/10.1016/0040-4039(95)00395-S (1995).

39. Natarajan, A. et al. Novel Arylsulfoanilide-Oxindole Hybrid as an Anticancer Agent That Inhibits Translation Initiation. J. Med. Chem. 47, 4979-4982, https://doi.org/10.1021/jm0496234 (2004).

40. Lakshman, M. K. et al. Facile synthesis of 1-alkoxy-1H-benzo- and 7-azabenzotriazoles from peptide coupling agents, mechanistic studies, and synthetic applications. Beilstein J. Org. Chem. 10, 1919-1932, https://doi.org/10.3762/bjoc.10.200 (2014).

41. Shao, C. et al. Carboxylic Acid-Promoted Copper(I)-Catalyzed Azide-Alkyne Cycloaddition. J. Org. Chem. 75, 7002-7005, https:// doi.org/10.1021/jo101495k (2010).

42. Sheldrick, G. M. A short history of SHELX. Acta Crystallographica, Section A A64, 112-122, https://doi.org/10.1107/ S0108767307043930 (2008).

43. Dolomanov, O. V., Bourhis, L. J., Gildea, R. J., Howard, J. A. K. \& Puschmann, H. OLEX2: a complete structure solution, refinement and analysis program. J. Appl. Crystallogr 42, 339-341, https://doi.org/10.1107/S0021889808042726 (2009).

44. Sheldrick, G. M. SHELXT - Integrated space-group and crystal-structure determination. Acta Crystallogr. Sect. A: Found. Crystallogr A71, 3-8, https://doi.org/10.1107/S2053273314026370 (2015).

45. Brittain, W. D. G. et al. Simultaneous Clicknetic Resolution Coetaneous catalytic kinetic resolution of alkynes and azides through asymmetric triazole formation. ChemRxiv. https://doi.org/10.26434/chemrxiv.5663623.v1 (2017).

46. Payne, D. T., Fossey, J. S. \& Elmes, R. B. P. Catalysis and Sensing for our Environment (CASE2015) and the Supramolecular Chemistry Ireland Meeting (SCI 2015): Dublin and Maynooth, Ireland. 8th-11th July. Supramol. Chem. 28, 921-931, https://doi.or g/10.1080/10610278.2016.1150595 (2016)

47. Fossey, J. S. \& Brittain, W. D. G. The CASE 2014 symposium: Catalysis and sensing for our environment, Xiamen 7th-9th November 2014. Org. Chem. Front. 2, 101-105, https://doi.org/10.1039/C4QO90045F (2015). 


\section{Acknowledgements}

J.S.F., A.G.D. and W.D.G.B. would like to thank the University of Birmingham for support. B.R.B. thanks Loughborough University and Research Councils UK for a RCUK Fellowship. J.S.F. would like to thank the Royal Society for an Industrial Fellowship and the EPSRC for funding (EP/J003220/1). J.S.F., W.D.G.B. and B.R.B. acknowledge the support of a Wellcome Trust ISSF award within the University of Birmingham. All investigators are grateful for a Royal Society Research Grant (2012/R1) that underpins this project. Dr. Chi Tsang, Dr Peter Ashton and Dr Allen Bowden are thanked for helpful discussions about mass spectrometry and HPLC analysis respectively. W.D.G.B. would also like to thank the Royal Society of Chemistry, Society for Chemical Industry and the School of Chemistry at the University of Birmingham for travel grants facilitating productive discussions via the CASE Network ${ }^{46,47}$.

\section{Competing interests}

The authors declare no competing interests.

\section{Additional information}

Supplementary information is available for this paper at https://doi.org/10.1038/s41598-019-50940-4.

Correspondence and requests for materials should be addressed to B.R.B. or J.S.F.

Reprints and permissions information is available at www.nature.com/reprints.

Publisher's note Springer Nature remains neutral with regard to jurisdictional claims in published maps and institutional affiliations.

Open Access This article is licensed under a Creative Commons Attribution 4.0 International License, which permits use, sharing, adaptation, distribution and reproduction in any medium or format, as long as you give appropriate credit to the original author(s) and the source, provide a link to the Creative Commons license, and indicate if changes were made. The images or other third party material in this article are included in the article's Creative Commons license, unless indicated otherwise in a credit line to the material. If material is not included in the article's Creative Commons license and your intended use is not permitted by statutory regulation or exceeds the permitted use, you will need to obtain permission directly from the copyright holder. To view a copy of this license, visit http://creativecommons.org/licenses/by/4.0/.

(C) The Author(s) 2019 